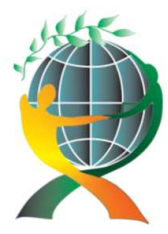

\author{
(online) $=$ ISSN $2285-3642$ \\ ISSN-L = $2285-3642$ \\ Journal of Economic Development, Environment and People \\ Volume 8, Issue 2, 2019
}

URL: $\underline{\text { http://jedep.spiruharet.ro }}$

e-mail: office jedep@spiruharet.ro

\title{
Another Acknowledgement on the American Strategy on the War in Iraq
}

\author{
Mohamed Raghad Raeed
}

The Department of International Relations and European Integration. The National School of

Political and Administrative Studies, Bucharest, Romania

\begin{abstract}
The main objective of this article is to describe and evaluate some of the central elements of the US strategy in Iraq, from the beginning of the war to the present. In this case, the term "strategy" refers mainly to the political-military actions directly related to the wider context of the war on terrorism. But the American strategy also involves secondary concerns: those that force the US, as a world power, to have constant commitments and implications in the evolution of the international system.

As a result, the US strategy is not just about how the US manages military, anti-terrorist, regional stabilization and nation-building operations in Iraq, but also about how Washington defines its priorities, its political and military actions, and allocates resources not just to achieve the central objectives, but also to solve various side problems of the international scene.

When talking about the current situation in Iraq, the starting point of the discussion must be the legitimacy of the US military intervention in 2003. From a strictly legal perspective, as from a strictly moral perspective, the US intervention in Iraq seems not to be legitimate enough. In order to establish a theoretical basis for the US intervention in Iraq, we must analyze the situation through the perspective of realism, as a theory of international relations, and we must recall some of Morgenthau's basic ideas.
\end{abstract}

Keywords: Iraq-war, US strategy, realism theory, terrorism theory, political interest, international relations, economic power, democracy, American phobia

JEL Codes: H6, N40

How to cite: MOHAMMED, R. (2019). Another Acknowledgement on the American Strategy on the War in Iraq. Journal of Economic Development, Environment and People, 8(2), 37-44. doi:http://dx.doi.org/10.26458/jedep.v8i2.630

\section{Introduction}

The Region of Middle East is characterized by conflicts over the past decades. To a large extent, this is caused by the problems associated with nuclear weapons, terrorism and natural resources. On March 20, 2003, the war on terror took shape, with the Bush administration announcing the start of a war against Iraq. The war was allowed in order to kill the Iraqi dictator Saddam Hussein, believed to be linked to al-Qaeda, and to destroy the alleged mass destruction weapons identified on the Iraqi territory (Murray, 2003). The eight-year war between the United States and Iraq from 2003 to 2011 has become one of the biggest conflicts in the past twenty years in this region. For the founder of the realistic school, the main pillar of any discussion of international relations is "the concept of interest defined in terms of power" (Morgenthau, 


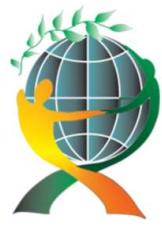

\author{
(online) $=$ ISSN $2285-3642$ \\ ISSN-L = 2285 - 3642 \\ Journal of Economic Development, Environment and People \\ Volume 8, Issue 2, 2019 \\ URL: http://jedep.spiruharet.ro \\ e-mail: office jedep@spiruharet.ro
}

1964). Power, that is defined in the context of international relations as "the control exercised by man on the minds and actions of other people" (Morgenthau, 1964; Rolfsen, 2002). So far, Morgenthau's references to the concepts of interest and power are unclear. But things get clearer if we take into account his following statement: "Whatever the material objectives of an external policy, such as the procurement of new sources of raw materials, the control of maritime routes or territorial changes, they always assume control of the actions of others by influencing their minds" (Morgenthau, 1964). This fragment refers to raw materials, territories, and trade routes. All those three elements are present, directly or indirectly, in the third part of Morgenthau's work, entitled "National Power" (Morgenthau, 1964).

The central elements of this part of Morgenthau's work are the enumeration and discussion of the relevance of the constituent elements of national power, as well as the interactions between these elements. If we carefully assemble all these observations, we have the opportunity to understand what the interest means, defined in terms of power within the reference system of international relations.

There is, however, in Morgenthau's work another element that is an important ingredient for an analysis such as this one. This is the fourth principle of political realism. In presenting this principle, Morgenthau (1964) states that "political realism is aware of the moral significance of the political action". But the founder of the realistic school asserts that the same school of thought "is also aware of the ineluctable tension between the moral precept and the requirements of successful political action". Moreover, Morgenthau states that, according to the elemental logic of political realism, "universal moral principles cannot be applied to the actions of some states in their universal abstract formulation, but must be filtered through the concrete circumstances of time and place" (Morgenthau, 1964).

In other words, the political actors should take into account the universal moral principles; it must also be stressed out that often, the good, as a central element of the most important moral precepts is openly contradictory to the logic of successful political action. In other words, it is clear that the success of political action can also mean that you have to do what from a strictly moral perspective is condemnable and bad. It should also be stressed that if we accept the existence of a universal principle stating that you should do good and avoid doing harm, that does not mean that this good is always the same thing and does not always produce the same concrete political and strategic consequences.

All these references to the issue of the relationship between good and bad political action can be assembled into another pair of complementary formulations:

1. the success of political action sometimes means doing what, from a strictly moral perspective, is bad or even awful;

2. in order to be able to obtain what politically and morally can be a meaningful and undeniable good result, you can be forced to commit acts that, from a strictly moral perspective, can sometimes be bad or even awful.

Morgenthau also discusses in a very detailed and much nuanced manner the issue of the huge difference in status, responsibility and behavior among actors with different ranks of power on the international arena. For the international system as a whole, peace, condemnation of aggression, avoidance of intervention, placement of sovereignty at the very top of a conceptually structured pyramid universe represent the supreme positive values. But it should not be forgotten that the international system is always made up of a multitude of small actors, who are the overwhelming majority and who, through the pressure of their large 


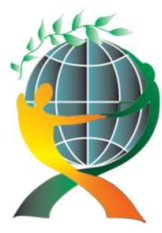

\author{
(online) $=$ ISSN $2285-3642$ \\ ISSN-L = $2285-3642$ \\ Journal of Economic Development, Environment and People \\ Volume 8, Issue 2, 2019 \\ URL: http://jedep.spiruharet.ro \\ e-mail: office jedep@spiruharet.ro
}

number, impose certain values or behaviors as desirable or even mandatory, and from a small number of great powers. These great powers are actors of the international system that act, according to a different logic from that which animates the international activity of the small and medium world powers.

Martin Wight (1998) states in his work "Power Politics" that "the most frequently mentioned theme in international history is not the development of internationalism", but "is the series of efforts made by the great powers to win the supremacy of the state system"(Wight, 1998).

As in previous times of the universal history, superpowers can develop imperialist behaviors, with objectives aimed at "dominating the entire politically-organized globe", that is, creating and operating a true "world empire" (Morgenthau, 1964). A gigantic task, that involves a type of political action that is different from the actions that lie within the reach of small powers.

It is equally improper to try to understand the current US behavior, in relation to the behavior of small or medium-sized powers, such as Belgium, Romania or Japan. It would be like trying to compare the metabolism and the behavior of an elephant to those of a mouse. And that's because mice do not resemble elephants, just as superpowers do not resemble in their actions, to the much less powerful states and therefore secondary to the international scene.

\title{
1. Applying the Theoretical Premises to the Situation from Iraq
}

After reviewing some of the ideas found in the works of important authors of the realistic school of international relations, we are going to apply these ideas and the conclusions that we have drawn to

the concrete reality of the US intervention in Iraq. Thus, we obtain several assertions that can be considered as simple working hypotheses:

Hypothesis 1. If we accept that the understanding of international relations is centered on studying the behavior of interest-bearing actors, that are defined in terms of power, and that the natural purpose of any actor from the international scene is to maximize its power, we can say that the military intervention of the US in Iraq is in line with the geostrategic component of the US national interests, and that, in the current context, the US, with significant forces in the Middle East, is stronger, better positioned and more influential than before the spring of 2003 .

This does not mean, however, that the mere American military presence can stabilize and bring peace to the entire region. On the contrary, there are opinions that argue that throughout the Middle East, things have taken a much more dangerous turn than by the time of the American intervention.

Hypothesis 2. Returning to the perspective of the realistic theory for a better understanding of the current developments from Iraq, we can assert that if we accept that there is an "ineluctable tension" between moral precepts and political efficiency, it results that the analysis of the Iraq war and the prolongation of the US military presence in the area, with the help of conceptual instruments of a moral nature, cannot lead to scientific knowledge, on the contrary, we have to discuss the real efficiency of the US actions. On the other hand, if we are talking about the efficiency of the US military-political action, it is very likely that we will encounter many episodes that, viewed from a strictly moral perspective, are characterized as an absolutely bad thing. For example, in early 2006, there was an episode in Iraq that allows highlighting 




\author{
(online) $=$ ISSN $2285-3642$ \\ ISSN-L = $2285-3642$ \\ Journal of Economic Development, Environment and People \\ Volume 8, Issue 2, 2019 \\ URL: http://jedep.spiruharet.ro \\ e-mail: office jedep@spiruharet.ro
}

the enormous amount of errors and horrors that the contemporary warfare contains, despite the modern equipment and weapons used. An unmanned US plane has identified three men digging a pit near a road close to Baiji, situated on the north side of Tikrit. I have to mention that Saddam Hussein originates in Tikrit and as a result the US military has every reason to be concerned about the special monitoring of a region where anti-Western feelings and armed resistance could be significantly stronger than in the rest of the country. The Iraqi group seemed to be involved in an activity that, according to a US military force release, "respects the usual pattern of bombing in the vicinity of the road". The men were carefully monitored until they entered a building that was immediately hit by the multinational coalition forces with guided munitions launched by a combat aircraft. Local authorities briefly informed that this bombing mission resulted in at least six victims, including women and children. These events gave birth to a lot of negative feelings and repulsion from the local community. Such episodes lead to the alienation of an increasing number of military operations theater inhabitants. For such human communities, the liberators are quickly becoming slanderous criminals. And such individual and collective beliefs can only enormously complicate the task of political actors and armed forces that fight against entities that generate instability, tensions and terrorism.

The aforementioned episode highlights some important characteristics of the chronological conflict in Iraq, which has as protagonists the Americans and their allies, and in the opposite camp, the Muslim local radicals or the Muslim radicals coming from other regions of the Islamic world, with the purpose of killing the unbelievers. The same episode also radiographs the limits and constraints faced by US and the Allied forces in the Middle East. The same episode may also lead to prospecting the future of the Middle East conflicts; or, more specifically, to explore alternative scenarios for the future of this area.

One of the important features of the events occurring amidst the US intervention in Iraq is the very strong American phobia that is seriously worsened by any big or small error committed even

involuntarily by Americans and their allies. For some radical Islamists, the Western-style market economy, the modern capitalism represents what Muslims call jahiliyya, that is, an age of ignorance, barbarity. For such thinkers "it is the sacred duty" of all "Muslims to push back the expansionary march of capitalism"(Sayeed, 1995).

Another obvious feature of the US involvement in Iraq is the insufficiency of forces used by the US and the Allied countries to control and restore peace in the region. It is not to be forgotten that Iraq is a country with a total area of 438,320 square kilometers, and a total population of $23,600,000$ (in 2002), a $75 \%$ urbanization rate (in 1997), and a capital city with 4,336,000 inhabitants (Gamblin, 2004). To control this vast area, the US forces, allies and partners have a total of about 250,000 troops. Apparently, the figure is more than enough and it appears that there would be more than one military for every two square kilometers of the Iraqi territory. In reality, things are totally different because an important part of any modern military force is made up of uncompetitive elements such as officials, drivers, maintenance workers, chefs, construction and logistics support units, medical units, etc. The share of non-combatant military personnel may, in some cases, amount to up to $90 \%$ of total staff. Let's assume that in Iraq the non-combatant military personnel is much lower - say only $30 \%$ of the total American and Allied forces. This means that, in reality, out of about 250,000 soldiers, only 175,000 can be used in patrol, surveillance, and battle missions. Apparently, even this diminished figure compared to the initial one is sufficient; this would result in a responsibility area of only about 2,502 square kilometers for each American or ally military man. However, 




\author{
(online) $=$ ISSN $2285-3642$ \\ ISSN-L = $2285-3642$ \\ Journal of Economic Development, Environment and People \\ Volume 8, Issue 2, 2019 \\ URL: http://jedep.spiruharet.ro \\ e-mail: office jedep@spiruharet.ro
}

such a calculation is actually a trap, a seemingly valid procedure that seriously distorts the reality. And this is because the military service resembles to any other human activity that takes place in three shifts: about one third of the military personnel is at any moment on the mission, a third is resting, and the last third is ready to intervene if necessary, in a relatively short time. This simple calculation suddenly leads to the understanding that the actual number of US, allied and partner military men participating at any given time in patrol and combat missions is rather close to just 60,000 people. Of which perhaps half are destined for missions such as guarding targets and escorting convoys carrying live force, ammunition, armaments or supplies. This means that there are only about 30,000 - or no more than 40,000 - of soldiers who can be used simultaneously to actively maintain control over a country with a total area of nearly 438,000 square kilometers.

According to this calculation, each American, ally or partner soldier is therefore responsible for ensuring the peace and security on an area of nearly 11 square kilometers. If we talk about desert or semi-desert regions of Iraq, a soldier every 11 square kilometers might be enough. However, when it comes to urban areas that, as mentioned above, concentrate $75 \%$ of the country's population, then the situation is quite different. A soldier cannot control an area of 11 square kilometers of a city, whether it is made up of traditional or modern buildings. In order to keep an urban area under control, it would be required a minimum of two or three hundred soldiers in key locations or patrol missions, as well as at least one or two intervention teams. If we sum up the figures, we reach 260-360 needed troops for every $11 \mathrm{~km}$ of urban space. That's 260 to 360 times more than the US military men that where meant to keep the Iraqi neighborhoods and cities under control. But the allocation of an additional number of soldiers, which was absolutely necessary for the control of urban areas, meant the diminution of military personnel usable to control the rest of Iraqi territory; and as the situation in Iraqi cities was more unstable and required more personnel, the less patrolled and controlled the desert and semi-desert regions would remain. As a result, supervision through technical means, although it may lead to regrettable accidents, such as the one mentioned above, remains virtually the only method that can replace the lack of military personnel.

\title{
2. American Presence in Iraq and the Public Perception of War
}

At the beginning of the war, the Americans were perceived as liberators by the Iraqi population, because they removed Saddam Hussein from power. Soon the local population's perception changed into a bad reputation being supported by some well-documented cases, such as the famous torture cases of prisoners from Abu Ghraib and other places of detention Hersh, 2004). The latest evidence clearly shows that these acts of torture were not accidentally practiced but that they took place as a result of the US Department of Defense policy. The abominable acts committed by some American soldiers, such as rapes followed by killing the whole family to clear the traces or the massacres among civilian populations as a result of the killing of some American comrades; disregarding the local customs and religion: there have been cases in which the Qur'an, the holy book of Islam, has been burned, many sexually taboos imposed by Islam have been laughed at, etc. Amongst a population that is mostly religiously fundamentalist, these acts could only lead to a state of anti-American revolt. 




\author{
(online) $=$ ISSN $2285-3642$ \\ ISSN-L = $2285-3642$ \\ Journal of Economic Development, Environment and People \\ Volume 8, Issue 2, 2019 \\ URL: http://jedep.spiruharet.ro \\ e-mail: office jedep@spiruharet.ro
}

In Iraq almost no one believes in Bush's reasons for the war; the people rather believe that the country's economic interests are being ignored and that foreign companies especially the American ones, are seeking to put their hands on the resources of the country. And the politicians who facilitate these changes are considered to be the puppets of the Americans.

On the other hand, the Western public opinion is becoming increasingly more intolerant of what we often call collateral losses. When a precision air strike, executed with guided ammunition destined to kill terrorists, accidentally kills some civilians, the entire Western world is shaken by protests, criticism, pamphlets, parliamentary interrogations and devastating acidic press articles.

Such reactions can only lead to the paralysis of the reactionary capacity of US and Allied military personnel, not only in Iraq, but anywhere in the world. If the accidental killing of a civilian automatically leads to the fact that the military man who committed that error is endlessly criticized by a whole world, who condemns him with vehemence for the error committed, the ultimate effect will be devastating for the interests of the civilized world. Finally, the soldiers that the Western world and its allies send to fight against terrorists will prefer not to act when it is necessary, in order to avoid a possible mistake and the criticism that would follow it. But we must mention that in the war against terrorism there were registered regrettable losses on the part of both parties. Since the invasion on March 20, the US-led multinational force lost about 4,300 people in Iraq; most of them American citizens. This is all the more strange since in the West until recently didn't have any trouble accepting the regrettable but inevitable collateral losses. A good example issues from General Dwight D. Eisenhower's memoirs; he became President of the United States precisely because the people rightly appreciated him for the strategic thinking and the strength of character that he showed during the war time.

Within the context of the liberation of France from the German's occupation, one of the strategic objectives that the forces commanded by Eisenhower had to fulfill was to paralyze the displacement and maneuverability of the German reserve forces. But, according to Eisenhower, it was very clear that, although tactically, operationally and strategically necessary, "the destruction of the main bridges, freight stations and the most important railways of France would lead to inevitable losses in the ranks of the civilian population" (Eisenhower, 1975). Statisticians calculated that "the air strike will cost at least 80,000 lives" (Eisenhower, 1975). What can be understood from this is that no one puts first the need to completely eliminate the collateral losses; the British Prime Minister Winston Churchill was frightened when he learned about the statistics, but not because of the total number of victims, but rather because of the political consequences of the collateral losses. Churchill said about the air strikes on the French railway system that "post-war France must become our friend", and in this case avoiding the killing of too many civilians "is not only a matter of humanitarianism but also of a high state policy" (Eisenhower, 1975). Linked to the strategic bombing dispute, Eisenhower stated that "the losses suffered by the civilian population only reached a fraction of the figures predicted by the statisticians, but the entire French people accepted them calmly as a necessity, without showing any animosity against the Allied forces because of them " (Eisenhower, 1975). 


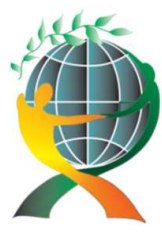

\author{
(online) $=$ ISSN $2285-3642$ \\ ISSN-L = $2285-3642$ \\ Journal of Economic Development, Environment and People \\ Volume 8, Issue 2, 2019 \\ URL: http://jedep.spiruharet.ro \\ e-mail: office jedep@spiruharet.ro
}

Once Eisenhower's memoirs analyzed, we noticed that he was detached to the problem of collateral losses. And this was normal, as long as "the subsequent events would clearly show how important the contribution of the aerial bombardments was to the success" (Eisenhower, 1975) against the military forces of Nazi Germany. In other words, Eisenhower thought that if the final result of aerial bombardment is the defeat of the German armed forces and the liberation of France, a few hundred or even a few thousand dead French civilians do not represent an exaggerated price. According to Eisenhower's memoirs, it is important that collateral losses do not prove to be too big or unnecessary. Most likely, if Eisenhower was still alive and ordering the armed forces of the US today, he would have been described by the ultra-liberal commentators as an abject monster, thirsty with blood.

Returning to the situation in Iraq (Rayburn,2019), we see first of all that such commentators primarily ignore the fact that the mission of the US and allied military commanders in Iraq is, among other things, to save the blood of US and Allied troops, and not that of the Iraqi terrorists and their accomplices, and secondly that, although regrettable, collateral losses must be viewed in wartime as inevitable and, thus, perfectly justified from the point of view of the strategic interests, especially if they prove to be really useful (Keir, 2019).

\title{
3. Conclusions
}

The Iraq war is one of the most significant conflicts from the Middle East region, with both economic and social consequences on a long run. Possessing significant resources, Iraq plays a particular role in the international relations system. The war determined the development of Iraq according to a certain scenario; unfortunately this happened in a not too attractive way; today the country is defined by political and economic instability and is unlikely to be able too soon to get out of it.

This paper tried to explain the causes of this war; now it is more clear why the US Government decided to act and promote its own interests in this region. The paper outlines different points of view to describe, evaluate the central elements of the US strategy and assess also the impact of the American strategy on the outcome of the war. The USA policy in this region was examined with the help of various 'pursued in this war, and which were merely proclaimed. In addition, it was analyzed how the lack of military capacity influenced the results of the military operations.

The declarative goals of the American strategy were connected with the accusation of Saddam Hussein and with the fact that he was keeping weapons of mass destruction on the territory of Iraq (Ashok, 2016), and also cooperates with the Al Qaeda terrorist group. Concluding that Saddam Hussein representing a threat to the national security of Iraq, the United States decided to invade the country and a lengthy conflict began.

The real priority of the United States was to create a democratic Middle East, where Americans could act in their own interests, and an Iraq that would be open to the Eastern politics and culture. In addition, the Iraq war is a unique example where one state tried to "redraw" another in accordance with its own interests. And though this experiment has failed, it is an interesting phenomenon which deserves to be studied. Since the war ended, every day new materials, opinions and documents appear that can become the basis for the 




\author{
(online) $=$ ISSN $2285-3642$ \\ ISSN-L = $2285-3642$ \\ Journal of Economic Development, Environment and People \\ Volume 8, Issue 2, 2019 \\ URL: http://jedep.spiruharet.ro \\ e-mail: office jedep@spiruharet.ro
}

further development of this topic. This is due to the fact that, despite the formal end of the war, the United States still intervenes in Iraq's domestic politics. This article can be used to understand Iraq's point of view from the perspective of the American invasion, but it can also serve to understand the strategic position the US that caused it to act in order to assure its global hegemony and power in the international system. From the realistic perspective it is easier to understand the American strategy in the Iraq war as it has put into practice "the concept of interest defined in terms of power" (Morgenthau,1993).

\title{
References
}

[1]. Ashok Bhatnaga, (2016), Lightweight Ballistic Composites Military and Law-Enforcement Applications, 2nd Edition, Woodhead Publishing, eBook ISBN: 9780081004258

[2]. Eisenhower, D.D., (1975), "Cruciadă în Europa", Ed. Politică, Bucharest, pp. 321-322.

[3]. Gamblin, A., (2004), "Economia lumii", Ed. Ştiinţelor Sociale şi Politice, Bucharest, p. 154.

[4]. Hersh, S.M., (2004), "Torture at Abu Ghraib", Annals of National Security, available at:

[5]. https://www.newyorker.com/magazine/2004/05/10/torture-at-abu-ghraib (accessed 03 March 2019).

[6]. Keir Giles, (2019), Command Decision: Ethical Leadership in the Information Environment, SSI, https://publications.armywarcollege.edu/pubs/3692.pdf.

[7]. Morgenthau, H. J. (1964), "Politics among Nations: The Struggle for Power and Peace", $3^{\text {rd }}$ Eds., Revised

[8]. and Reset, Alfred A. Knopf, Inc., New York, pp. 5-148.

[9]. Morgenthau, Hans J, (1993), Politics Among Nations - The Struggle for Power and Peace, New York,

[10]. Mcgrew Hill Murray, W. and Robert, H. (2003), "The Iraq War: a Military History", Mass. Belknap Press of Harvard, University Press, Cambridge.

[11]. Rayburn, COL Joel D., COL Frank K. Sobchak, (2019), The U.S. Army in the Iraq War - Volume 1: Invasion Insurgency - Civil War, 2003-2006, Edited by: LTC Jeanne F. Godfroy, COL Matthew D. Morton, COL James S. Powell, LTC Matthew M. Zais, SSI, US Army War College.

[12]. Rolfsen, Raag (2002) "Political Realism and the Ethics of Vulnerability: The Need for a New Understanding of Security after September 11", in PACEM, 5:2, 2002: 115-136.

[13]. Sayeed, K., (1995), "Western Dominance and Political Islam: Challenge and Response", State University of New York Press, Albany, p. 36.

[14]. Wight, M., (1998), "Politica de putere", Ed. Arc, Chişinău, p. 38.

[15]. The Oxford Dictionary of Islam. Available at: http://www.oxfordislamicstudies.com/article/opr/t125/e1157\# (accessed 22 February 2019).

[16]. https://ahec.armywarcollege.edu/CENTCOM-IRAQ-papers/index.cfm, SSI, US Army War College,https://publications.armywarcollege.edu/pubs/3671.pdf 